\title{
Çocuk Müzelerinde İç Mekân Tasarımları: Atatürk ve Çocuk Müzesi İncelemesi
}

\section{Children's Museums Interior Designs: Ataturk and Children's Museum Examination}

\section{Hülya Yavuz Öden*®}

\section{Öz}

Müzeler, eğitim kuruluşlarına ve topluma hizmet etmekte olan kurumlardır. Müzelerin kendi uzmanlık alanına göre sergilenecek nesneleri toplaması, sergilemesi ve koruması gibi görevleri bulunmaktadır. Sergilenecek olan nesnelerin tarihini tespit etmek ve ziyaretçilere objelerle ilgili bilgi vermek bu kurumların amaçları arasındadır. Günümüzde müzelerin sergileme amacının yanında eğitim verme görevini de üstlenmeye başladıkları görülmektedir. Çağdaş müzeler, çocukların ve ailelerinin hafızasında daha fazla yer almayı ve bu sayede toplumun kültür seviyesini arttırmayı hedeflemektedir. Çocuklara müzedeki eserlerle ilgili sadece bilgi vererek dikkatlerini çekmek daha zor olduğu için onlara dokunarak, görerek ve uygulayarak eğlenceli bir deneyim yaşatılması gerekmektedir. Çocuk müzesi uygulamaları, genellikle tarih veya bilim konusunda özelleşmiş müzelere ek olarak yapılan bölümlerde görülmektedir. Bu sayede tarih, sanat ya da bilimi çocukların daha etkileşimli olarak deneyimlemesi sağlanmaktadır.

Bu çalışmada çocuk müzesi olarak yurtdışında uygulanmış örnekleri ele alınmışır. Ayrıca öncelikli olarak çocukların hedef kitle olduğu müzelerden olan Atatürk ve Çocuk Müzesi iç mekân ve sergileme elemanları bakımından incelenmiştir. Makalede amaçlanan, çocuklara yönelik tasarlanmış olan müzeleri etkinlik içerikleri bakımından araştırmak ve iç mekânında bulunan sergileme elemanlarının klasik müze anlayışındaki müzelere göre farklarına dikkat çekmektir. Bu amaçla tasarlanmış olan müzelerde yönlendirme panoları, haritalar, sergileme üniteleri çocukların göz hizalarına uygun olarak tasarlanmakta ve etkileşimli sergileme elemanları kullanılmaktadır. Atatürk ve Çocuk Müzesi araştırmasında öncelikli hedef kitle olarak ilköğretim çağındaki çocukların seçildiği için iç mekânında renk ve sergileme üniteleri bakımından çocukların ilgisini canlı tutacak formların ve bilgilendirme panolarının kullanıldığı görülmektedir.

\section{Anahtar Kelimeler}

Çocuk müzeleri, İç mekân, iç mimarlık, Atatürk ve Çocuk Müzesi, Yalova

\begin{abstract}
Museums are institutions that serve educational institutions and society. Museums have purposes such as collecting, exhibiting, and protecting objects to be exhibited according to their area of its expertise. It is among the aims of these institutions to determine the history of the objects to be exhibited and to inform visitors about the objects. Today, museums have started to take the duty of education in addition to the purpose of exhibition. Modern museums aim to be more in the mind of children and their families, thereby increasing the cultural level of society. It is difficult to keep the attention of children when giving information about works in the museum, so it is appropriate to have a fun experience by touching, seeing, and applying what they learn. Children's museum practices are generally seen in the sections made
\end{abstract}

* Sorumlu Yazar: Hülya Yavuz Öden (Dr. Öğr. Üyesi), Yalova Üniversitesi, Sanat ve Tasarım Fakültesi, İç Mimarlık Bölümü, Yalova, Türkiye. E-posta: hulya.oden@yalova.edu.tr ORCID: 0000-0002-5598-8162

Attf: Yavuz Oden, Hulya. “Çocuk Müzelerinde İç Mekân Tasarımları: Atatürk ve Çocuk Müzesi İncelemesi.” Art-Sanat, 14(2020): 533-556. https://doi.org/10.26650/artsanat.2020.14.0020 
in addition to museums that are specialized in history or science. In this way, children are ensured to experience history, art, or science more interactively. In this study, examples of the concept of a children's museum applied in foreign countries are given. In addition, "Ataturk and the Children's Museum", which is one of the museums where children are the target visitors, was examined in terms of interior space and display elements. The aim of the article was to investigate the museums designed for children in terms of their content and to examine the exhibition elements inside. In the museums designed for this purpose, direction boards, maps, and display units are designed in accordance with the children's eye alignments and interactive display elements are used. Since primary school children were chosen as the primary target group in the study of Ataturk and the Children's Museum, in the interior, forms and information boards are used to keep children interested in terms of color and display units.

\section{Keywords}

Children museums, Interior design, Design, Ataturk and Children's Museum, Yalova

\section{Extended Summary}

A museum is an institution where works and objects related to the natural sciences, archeology, ethnology, history, the fine arts and technique are regularly exhibited. The museum aims to contribute to the development of human knowledge through these works and objects. Today's contemporary museums include exhibition areas, art workshops, libraries, and recreation areas. Children's museums are places where children learn through play and discovery in environments designed for them. Children's museums and museums areas designed for children, which are the subject of the research, should create a desire for discovery by children.

In order to gain scientific and cultural experiences, environmentally-friendly planning systems for children, children's libraries, and children's museums were established in our country and many other countries.

Children's museums create and provide workshops for children of different age groups and study classes for children. There are different ways of learning within these museums, which also includes playing games. The game has an important effect on learning because it activates all the senses of children and ensures that the information is permanent. In these museums, there are places where different cultures are introduced and the objects specific to that culture are experienced by children.

It is possible for children to experience cultural activities such as painting, drama, and music in these museums. In children's museums, it is the aim for a child to learn by living in a dream world and to obtain permanent information. The first children's museum in the world was founded in 1899 in the United States. Children's museums are institutions that offer learning management, including implementation. The Brooklyn Children's Museum, the Boston Children's Museum, the Canadian History Museum, Children's Museum Department, and the London Children's Museum (KidsQuest Museum) offer interactive displays. Museums such as the Boston Childrens Museum have become places that introduce the world to children and families and gives them various experiences. In the Canadian Children's Museum, children discover the history of coun- 
tries through play. Children's museums provide an enjoyable and permanent knowledge for a child's understanding of art, culture, and history. In the 'Dress up station' section of the London Children's Museum (KidsQuest Museum), children wear costumes of the heroes in the story and combine their imagination with these accessories.

Interior orientations in children's museums should be in an uncomplicated order. Direction signs, images, and maps should be appropriate for the size of children. Classical exhibition units or technological exhibitions are used together as display elements in the interior of contemporary children's museums. Stationary, dynamic, and interactive display techniques can be used together. Display elements such as kiosks, showcases, boards, and plinths are used. In museums designed for children, they are provided with interior fittings designed according to their size to feel closer to the space.

The Hasan Ali Yucel Children's Museum, the Ataturk and Children's Museum are some of the museums designed for children in Turkey. The Ataturk and Children's Museum is located in Yalova. The founder and first president of the Republic of Turkey, Mustafa Kemal Ataturk, used this place as temporary housing when he came to Yalova. There is a reception area on the ground floor of the two-storey building and a graphic design on the ground about the places to be seen in Yalova. Display units with interactive display elements and videos are installed. In the museum, there are information boards about Atatürk and his spiritual children, and information about Ataturk's studies in education. The exhibition units in the Ataturk and Children's Museum are designed for primary school children to read the texts about Ataturk and his spiritual children and to learn about them using an interactive board. The display elements are used in different depths and colors on the same surface. On the second floor there is a section where children can do painting activities. Although it was not designed as a children's museum, as in the example of the Ataturk and Children's Museum, memorable information can be obtained by tapping and interacting, especially where primary school age children are the primary target visitor. The rooms are divided into certain concepts. In the interior design and display elements of the Atatürk and Children's Museum, warm colors and dynamic forms are used to attract the attention of children. As in this museum and other museums designed for children, the dimensions of the exhibition elements are designed at a height that children can reach.

As a result, interactive children's museums need to be established in order to ensure that the knowledge and education of children is permanent. In Turkey, the increase in the number of display samples used ins interactive museums will have a significant impact on education. In museums planned for children, using digital bases and video presentations for research, and using the beneficial aspects of technology, will be beneficial for the cultural development of young people. 


\section{Giriș}

Kelime kökeni Yunanca ‘Mouseion’ olan müzeler, 18. yüzyılın sonlarında oluşmaya başlamıştır. 19. ve 20. yüzyılda ise müzecilik uygulamaları gelişme göstermiştir. Müze; doğa bilimleri, arkeoloji, etnoloji, tarih, güzel sanatlar ve teknik ile ilgili birtakım eserlerin ve kalıntıların düzenli biçimde sergilendiği kurumdur. Müze, sergilediği bu eserler yoluyla, insanın bilgisinin artmasına katkıda bulunmayı amaçlamaktadır ve görerek ve tanıyarak öğrenme açısından büyük öneme sahiptir. Müze kurma ve işletme uzmanlık gerektiren özel bir meslektir. ${ }^{1}$ Müzeler kendi uzmanlık alanındaki objeleri bir araya getirerek ziyaretçilere sunmaktadırlar. Etkili sergileme yöntemleriyle bildiğimiz objeleri hatırlatma ya da bilmediklerimizi bize öğretmeyi amaçlamaktadırlar. Bu sayede kişinin öğrenmeye olan isteğini arttıran sergileme yöntemlerini ve uygulamaları da içine alarak öğrencilere, öğretmenlere ve toplumdaki bütün kesimlere öğrenme için mekân sağlamış olurlar. Günümüzdeki çağdaş müzelerde bulunan sergileme alanları, sanat atölyeleri, kütüphaneleri ve dinlenme alanlarıyla müzeler, ziyaretçilerine müzeyi gezerken dikkatlerini koruyan ve kalıcı bir öğrenme yöntemi sunan mekânlar oluşturmaktadır. ${ }^{2}$

Müzeler günümüzde bilim, kültür ve sanat ürünlerini sergileyen ve teknolojinin kullanıldığı öğrenme merkezleri işlevini de yürütmektedir. 20. yüzyılın başlarından itibaren müzeler eskiden olduğu gibi sadece belirli koleksiyonların sergilenmesi ve bakımlarının yapılması işleviyle yetinmemektedir. Aynı zamanda uygulamanın içinde barındığı eğitim etkinliklerinin yürütüldüğü mekânlar hâline gelmiştir. Bu eğitim işlevini de içinde barındıran müzeler, öncelikle çocuklara ve bunun yanında onların ailelerine de farklı deneyimler kazandırmaktadır³.

Araştırmaya konu olan çocuk ve çocuklara yönelik tasarlanmış müzeler, çocuklarda keşfetme isteği yaratan ve farklı yaş grubundaki ziyaretçilerin ilgi alanlarına yönelik atölyeler ve çalışma sınıfları bulunduran mekânlardır. İşlevleri içerisinde oyun oynamayı da barındıran bu müzelerde öğrenmenin farklı yolları uygulanmaktadır. Oyun oynamanın çocukların tüm duyularını harekete geçirmesinden dolayı öğrenmede önemli etkisi bulunmaktadır ve bu sayede bilginin kalıcı olmasını sağlamaktadır. Okula giden ve okul öncesi dönemdeki çocuklar için öğrenmenin kalıcı olmasını destekleyen deneyimler için, okul dışında da öğrenme kaynakları gerekmektedir. Bu nedenle çeşitli eğitim etkinlikleri okul tarafından ya da ailelerin desteğiyle okul d1şında da çocuklara sunulmaktadır ${ }^{4}$. Bilimsel ve kültürel deneyimlerin kazanılması için çocuklara yönelik tasarlanmış bilim merkezleri, çocuk kütüphaneleri ve çocuk

1 “Müze,” Grandmaster Genel Kültür Ansiklopedisi, c. 4 (İstanbul: Milliyet Yayınları, 1992), 990.

2 Serap Buyurgan, "Yaşayan ve Yaşatan Müze," Yaratıcı Drama Dergisi 12 (2017), 127.

3 Ceren Karadeniz, “Avrupa'da Çocuk Müzeleri: Frankfurt ve Hamburg Örneği,” Folklor/Edebiyat Dergisi 63 (2010), 178.

4 Özge Kandemir ve Özlem Uçar, "Değişen Müze Kavramı ve Çağdaş Müze Mekânlarının Oluşturulmasına Yönelik Tasarım Girdileri," Sanat ve Tasarım Dergisi 5 (2015), 17. 
müzeleri ülkemizde ve diğer pek çok ülkede kurulmaktadır. 1899 yılında ilk olarak kurulan çocuk müzeleri, çocuklara pek çok eğitim aktiviteleri sunmakta ve yaşayarak öğrenme deneyimini kazandırmaktadır. Bu müzelerde çocuklar deneyimleyerek öğrenme ve kültürel değerleri tanıma firsatı bulmaktadır. Bu çalışmada Amerika, Kanada ve İngiltere'de bulunan dört çocuk müzesinin içerisinde sunulan etkinlikler hakkında araştırma yapılarak Yalova'da bulunan Atatürk ve Çocuk müzesinde bulunan etkileşimli sergileme alanları incelenmektedir. Yurtdışında örnek olarak seçilen müzeler tarihsel önemi bakımından 1899'da ilk kurulan çocuk müzesi olan Brooklyn Children's Museum ve etkinlik alanları çeşitliliği sebebiyle farklı üç ülkeden seçilen müzelerden oluşmaktadır. Oyunun öğrenmede olan etkisinin uygulanmış örnekleri bakımından farklı ülkelerden örnek müzeler incelenmiştir.

Çalışmada betimsel araştırma yöntemi uygulanmıştır. Çocuk müzeleri ile ilgili yapılan çalışmanın araştırma aşamasında çocuk müzelerinin tarihi araştırılmış ve Yalova'da bulunan Atatürk ve Çocuk Müzesi ile ilgili yerinde belgeleme çalışması yapılmıştır. Kültür Bakanlığı ile yapılan yazılı görüşme ile müzenin Kültür Bakanlığına bağlı olmadığ1 ve özel müze olduğu bilgisine ulaşılmıştır. Müzenin tasarımcısı olan Tetrazon tasarım ofisi ile müze hakkında yazılı görüşme yapılmıştır. Müzede yapılan araştırmada müze ziyaret edilerek müze görevlisi ile bireysel sözlü görüşme yapılarak çocuklarla yapılan etkileşimli uygulamalar hakkında bilgi alınmıştır. ${ }^{5}$ Müzenin krokisi oluşturularak ayrı odalardaki konseptlere göre sergileme elemanlarının olduğu bölümlerle ilgili bilgiler verilmiştir.

\section{Çocuk Müzeleri}

Çocuk müzeleri, çocukların kendileri için tasarlanmış ortamlarda oyun ve keşif yoluyla öğrendikleri yerlerdir. Çocuk müzeleri eğlenceli, çocuklara etkileşimli öğrenme deneyimleri kazandırmaktadır. Giderek karmaşıklaşan bir dünyada, çocuk müzeleri, tüm çocukların aileleriyle veya öğretmenleriyle oynayarak öğrenebilecekleri bir yer sağlamaktadır. ${ }^{6}$

Sergileme, müzede bulunan koleksiyonların belirli kurgu içerisinde temsil ettikleri temaya en uygun şekilde düzenlenmesidir. Bilimin etkin olması ile müzelerde de sergileme elemanlarında dokunmatik ekranlar, video sunumları gibi yöntemler kullanılmaya başlanmıştır. Çocuk müzeleri derneği, çocukların kendi yaş aralıklarındaki antropometrik ölçülerle uyumlu donatı elemanlarının kullanılmasının geliştirilmesine destek olmaktadır. Çocuk müzelerinde genel ziyaretçi yaşları 6-12 yaş olduğu için sergileme elemanlarında göz hizası $130 \mathrm{~cm}$ olarak belirlenmiştir. ${ }^{7}$

5 Müze görevlisi ile 11.12.2019 tarihinde yapılan bireysel sözlü görüşme.

6 “About Children's Museums," erişim 26 Nisan 2020, https://findachildrensmuseum.org/about/.

7 Mehmet Can Kazova, "Çocuk Müzesi ve Bilim Merkezlerindeki İç Mekân Standartları ve Tasarım Yaklaşımları”(Yüksek Lisans Tezi, Başkent Üniversitesi, 2019), 51. 
Erken çocukluk dönemindeki deneyimler entelektüel gelişim ile bağlantılı olduğu için oyunun merkezde olduğu etkinlikler öğrenme için de temel oluşturmaktadır. Bu kültürel veya bilimsel etkinliklerin bulunduğu çocuk müzeleri çocukların oyun ile öğrenmelerine yardımcı olmakta ve kalıcı bir bilgi oluşturmaktadır.

Çocuk müzeleri, eğitim amacı olan etkinliklerini video, film gibi görsel etkinlikler, bilgisayar oyunları ile dokun ve keşfet yöntemi ile, çalıştaylar düzenleyerek, yayınlar, kütüphane, kurs ve drama etkinlikleri ile gerçekleştirebilmektedir. Eserlerin ve bilgilendirmelerin sergilenmesi de müzenin hedeflediği yaş grubu açısından önemlidir. Çocuklara yönelik tasarlanmış müzelerde sergileme elemanlarının ve bilgilendirme panolarının yükseklikleri çocukların ulaşabileceği şekilde ayarlanmıştır. ${ }^{9}$ Müzede iç mekân tasarımı yapılırken sergilenen konunun seyirci tarafından adım adım keşfedilmesini sağlayacak bir düzenleme oluşturulmalıdır. Tasarımcı, etkileşimli sergileme elemanlarını, konu ile ilgili görselleri ve bilgilendirmeleri etkili şekilde yerleştirmelidir. ${ }^{10}$

Geleneksel müzelerde sergilenen objeleri deneyimleme olanağ 1 bulunmamakta buna karşın çocuk müzeleri öğrenmeyi daha fazla pekiştirmektedir. Bu müzeler, özellikle ilköğretim çağındaki veya okul öncesi dönemdeki çocukların deneyimlediği ancak yetişkinler için de farklı bir öğrenme yöntemi bulunduran mekânlar olarak tasarlanmışlardır. Bu müzeler, çocukların çevredeki olaylara ve tarihe olan ilgilerini arttırmayı hedefleyen, oyuna ve bilgiye dayalı etkinlikler sunan mekânlardır. ${ }^{11} \mathrm{Bu}$ mekânlarda sergileme düzenlemeleri de geleneksel müzelere göre farklıdır. Çocukların daha özgür hareket ettikleri etkileşimli sergileme elemanları ile donatılmışlardır. Çocuklara yönelik tasarlanan sergileme ve müze alanlarının amaçları, çocukların hayata yönelik konularda aileleriyle veya arkadaşlarıyla iyi vakit geçirerek deneyimler kazandığı öğrenme mekânı oluşturmaktır. ${ }^{12}$

Çocuk müzeleri aynı zamanda öğretmenler için de öğrenciler ile okul dışında paylaşacakları dokunarak ve uygulayarak öğrenmeyi kapsayan yaratıcı programlar uygulamaktadır. İlk çocuk müzelerinin kurulmasındaki amaç da bir koleksiyonu ya da bir nesneyi sergileme elemanının arkasından izlemektense, çocuklar ile anlatılmak istenen hikâyeyi eğlenceli bir şekilde buluşturmak olmuştur ${ }^{13}$. Bu müzeler aynı za-

8 Yaşare Arnas Aktaş, “Oyun, Öğrenme ve Deneyimin Birleşimi: Çocuk Müzeleri,” Yaratıcı Drama Dergisi 2 (2017), 17.

9 Vedat Özsoy ve Levent Mercin, "Sanat (Resim) Eğitiminde Müzelerin Kullanılmasında ilgili Kurum ve Kuruluşların Karşı1ıklı Görev ve Yükümlülükleri,” Türk Eğitim Bilimleri Dergisi 3 (Eylül 2003), erişim 10 Nisan 2020, https://dergipark.org.tr/tr/pub/tebd/issue/26131/275245.

10 Züheyla Aykut, "Müze sergileme Elemanlarında İzleyici- Sergi Etkileşimi Bağlamında Mekan Tasarımı" (Yüksek Lisans Tezi, Marmara Üniversitesi, 2017), 132.

11 Karadeniz, "Avrupa'da Çocuk Müzeleri: Frankfurt ve Hamburg Örneği,” 169.

12 Özge ve Özlem, "Değişen Müze Kavramı ve Çağdaş Müze Mekânlarının Oluşturulmasına Yönelik Tasarım Girdileri," 17-47.

13 Ceren Karadeniz, "Dünyada Çocuk Müzeleri ile Bilim, Teknoloji ve Keşif Merkezlerinin İncelenmesi ve Türkiye İçin Bir Çocuk Müzesi Modeli Oluşturulması” (Yüksek Lisans Tezi, Ankara Üniversitesi, 2009), 68. 
manda farklı kültürlerin tanıtıldığı ve o kültüre özgü objelerin çocuklar tarafından deneyimlenmesini sağlayan mekânlardır. Resim, drama, müzik gibi etkinlikleri bu müzelerde deneyimlemek çocuklar açısından mümkündür. Bilimin, güzel sanatların ve kültürün öğretilmesi için eğitim ortamı olarak müzelerin kullanılması gerekmektedir. Çocukların müzede kazanılan gözlemler ve deneyimler ile derslerde görülen bilgilerin ilişkilendirmesi ve daha sağlam bir şekilde bağ kurması sağlanmaktadır. Çağdaş müzeciliğin getirdiği yaratıcılık ve uygulamalar ile derslerde teorik olarak işlendiğinde kurulamayan bağlar bu sayede kurulabilmektedir. Çocuk müzelerinde sergilenen mimari elemanların ya da dönemle ilgili bilgilerin çocuklar tarafından oyun oynayarak zevkli ve heyecan verici olarak öğrenilebilmesinin yanında, öğrenilenlerin canlandırılarak sanatsal çalışmalar yapıldığı da gözlemlenmektedir. ${ }^{14}$ Tarihte yaşanmış olay ve yaşamış kişiler ile ilgili canlandırmaların çocuklara yaptırılması ile çocukların tarihteki olaylarla bağ kurması sağlanmaktadır. Müzelerin bu sebeplerle okul öncesi yaşlardan itibaren çocuklar için aynı zamanda bir eğitim kurumu olduğu görülmektedir ${ }^{15}$. Okul çağındaki çocukları müzeye getiren ve onlara okulda müzenin uzmanlık alanı ile ilgili bilgiler veren öğretmenler, bu konuları derslerinde işleyerek çocukların daha heyecanlı ve merak içinde müzeye gelmesini sağlayabilmektedir. Müzede uygulamalar ile öğrenen çocuklar derslerini daha etkili takip etmektedirler ${ }^{16}$. Çocuk müzelerinde çocuğun dünyası göz önüne alınarak koleksiyonlar yerleştirilmekte ve çocuğun yaşayarak öğrenmesi ve hayal dünyasını kullanarak bilgiyi kalıcı olarak edinmesi hedeflenmektedir ${ }^{17}$.

Çocuk müzelerinde iç mekân yönlendirmelerinin girişten çıkışa kadar yönlendirme levhaları, görseller, haritalar kullanılarak ve karmaşık olmayan bir sergi güzergâhı hazırlanarak oluşturulması gerekmektedir. ${ }^{18}$ Çağdaş çocuk müzesi ve bilim merkezlerinde dolaşım ve yönlendirme, ziyaretçilerin girişten çıkışa kadar olan zaman diliminde, doğru, anlaşılabilir ve güvenlikli bir yönlendirme anlayışı içinde, dolaşım güzergâhını tamamlamalarıyla gerçekleşmektedir. Çocuk müzesi ve bilim merkezi gibi küçük yaştaki bireylere hizmet veren müzelerde hareket etme ve yönlendirme yöntemlerinin belirlenmesi, çocuğun sergi alanı içinde güven içerisinde ilerlemesini sağlamaktadır. Müzeler, kaliteli zaman, eğlence ve öğrenme firsatları sunmaktadır. Çocuklara kendi kültürüyle bağlantı sağlayan müze deneyimleri aynı zamanda gelenekleri ve sahip oldukları değerleri tanımalarını da sağlayacaktır. Bununla birlikte oyun, öğrenme ile

14 Yüksel Göğebakan, "Alternatif Öğrenme Mekânları Olarak Müzelerin Eğitim-Öğretimde Kullanılmasının Önemi,” Atatürk Üniversitesi Güzel Sanatlar Enstitüsü Dergisi 40 (2018), 20.

15 Göğebakan, “Alternatif Öğrenme Mekânları Olarak Müzelerin Eğitim-Öğretimde Kullanılmasının Önemi," 22.

16 Nihad Shabbar, "Çocuklar İçin Müze Eğitimi," Kent Toplum Müze Deneyimler- Katkllar (İstanbul: Türkiye Ekonomik ve Toplumsal Tarih Vakfi Yayınları, 2001), 68-73.

17 Emine Kılıçoğlu, vd., "Dünya Ülkelerinde ve Türkiye'de Çocuk Müzelerine Bir Bakış," Çocuk ve Gelişim Dergisi 3 (2019), 45.

18 Kazova, "Çocuk Müzesi ve Bilim Merkezlerindeki İç Mekân Standartları ve Tasarım Yaklaşımları," 65. 
örtüşmektedir, çünkü erken gelişim aşamalarında çocuklar esas olarak oyun yoluyla öğrenmektedirler. ${ }^{19}$

\section{Çeşitli Ülkelerden Çocuk Müzeleri}

Çocuklar için tasarlanmış müzeler, diğer geleneksel müzeler gibi kültürel değerleri belgeleyen ve sergileyen kurumlardır. Eğitim faaliyetleri de bu kurumlarda uygulanmaktadır. ${ }^{20}$ Çağdaş çocuk müzelerinin iç mekânında sergileme elemanları olarak klasik sergileme üniteleri veya teknolojik sergilemeler bir arada kullanılmıştır. Durağan, dinamik ve interaktif sergileme teknikleri birlikte bulunabilmektedir. Kiosk, vitrin sergileme, panolar, kaideler gibi sergileme elemanları kullanılmaktadır. Kiosk, dokunmatik ve ses çıkışı olan bilgi ve dinamik sergileme sistemidir. ${ }^{21}$

Dünyadaki ilk çocuk müzesi Amerika Birleşik Devletleri'nde, 1899'da kurulan Brooklyn Children's Museum'dur. Çocuk müzeleri geleneksel müze kavramının d1şında çocuklara alternatif uygulamayı da içinde barındıran öğrenme olanakları sağlamaktadır. Çocuk müzeleri tematik müze kapsamında bulunmaktadır ve etkileşim ve eğitim alanlarıyla çocuklar için eğitime yardımcı mekânlar oluşturmaktadır. Brooklyn Children's Museum'un ana fikri, eğitim kaynağı olarak hizmet vermek, aileler ve çocukları için boş zamanlarında kullanabilecekleri bir mekân sağlamaktır. Bu müze okula giden ve gitmeyen tüm çocuklara faaliyetler sunan ve tamamen çocuklara yönelik ilk müzedir. ${ }^{22}$ İç mekânında geri dönüşümlü malzemeler, bambu, zeminde geri dönüşümlü kauçuk malzeme kullanılmıştır.

19 Natalia Filova, "Human Centered Design Of A Children's Museum," SWS Journal of Social Sciences and Art 2 (2019), 68.

20 Muna S1lav, "Museums For Children," Procedia - Social and Behavioral Sciences 122 (Mart 2014), 360, erişim 20 Nisan 2020, https://doi.org/10.1016/j.sbspro.2014.01.1354.

21 Mehmet Can Kazova. "Çocuk Müzesi ve Bilim Merkezlerindeki İç Mekân Standartları ve Tasarım Yaklaşımları," 58.

22 Denise Coelho Studart, "The Perceptions and Behaviour of Children and Their Families in Child-Orientated Museum Exhibitions" (PhD Thesis, University College London, 2000), 29. 
Tablo 1

Brooklyn Çocuk Müzesi'nden görünüm (https://www.brooklynkids.org/)

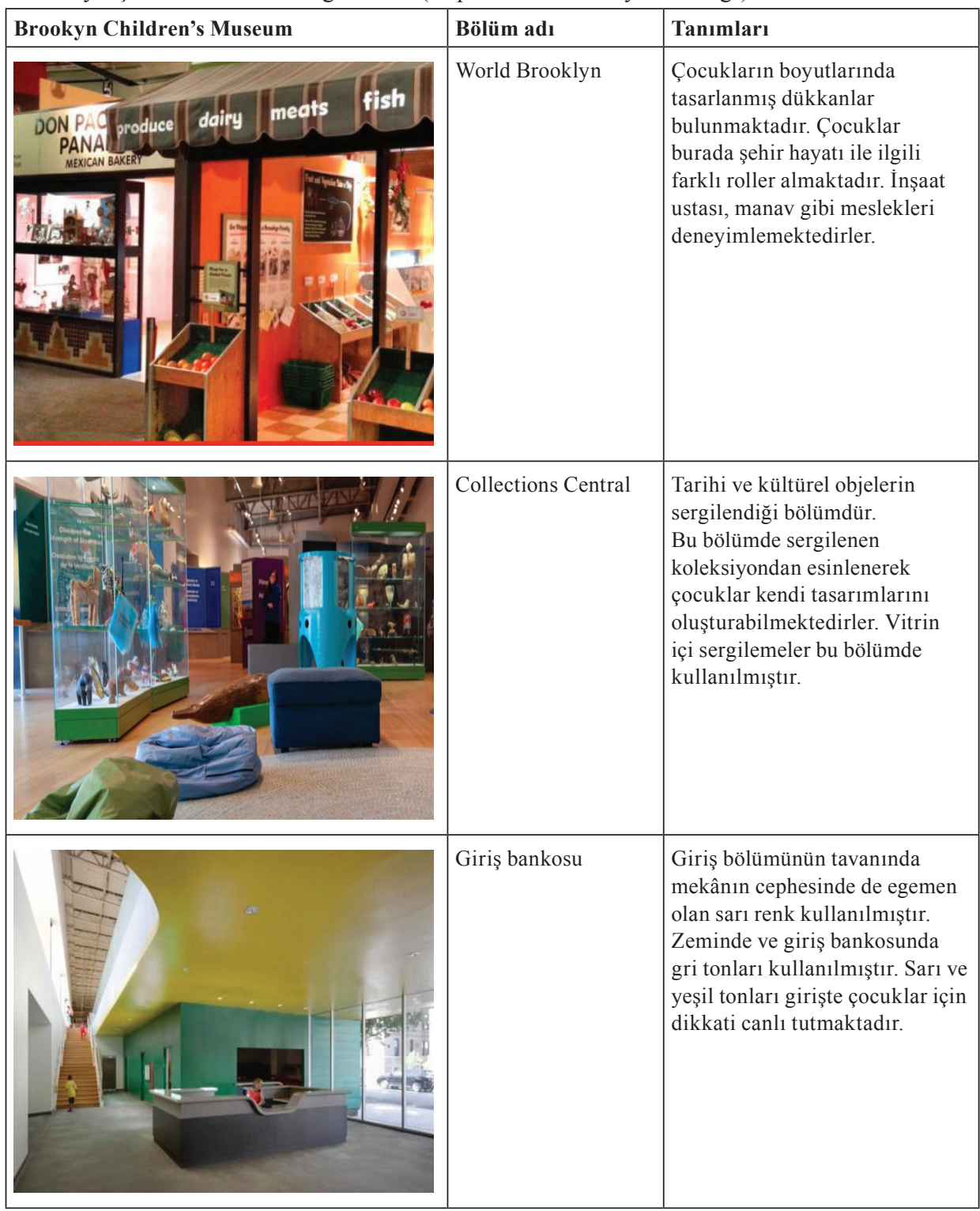

Brooklyn Children's Museum sergileri, çocukların sosyal, duygusal ve fiziksel gelişimlerini teşvik eden duyusal oyunlar için firsatlar sunmaktadır. Bilim merkezi, duyularını keşfedebilecekleri duyusal oda, Brooklyn World odası, Collections Centre, Neighbourhood Nature bölümü gibi deneyimlere dayanan bölümleri bulunmaktadır. Brooklyn Childrens Museum'da bulunan Brooklyn World bölümünde, çocuklar mahallelerinde bulunan dükkânlara benzer bölümlerde manav, bakkal, mimar gibi roller 
üstlenirler. Çocuklar, bu sayede yakınlarında bulunan dükkânlar ve işleyişleri ile ilgili bilgi sahibi olmaktadırlar. Neighbourhood Nature bölümünde mantar ve bitkilerin bulunduğu bahçede uygulamalı olarak deneyimlerde bulunmaktadırlar ${ }^{23}$.

Brooklyn Childrens's Museum sanat koleksiyonu müdür Willy Goodyear tarafindan kurulmuş ve çocukların meraklarını uyandıracak bir mekân olarak tasarlanmıştır. İç mekânında çocukların boyuna uygun sergileme elemanları ve metin panoları yerleştirilmiş, çocukların algılayabileceği dilde metinler oluşturulmuştur. ${ }^{24}$

Amerika'da kurulmuş bir diğer çocuk müzesi ise Boston Children’s Museum'dur. Boston Children's Museum, 1913 yılında kurulmuş ve çocuklara dünyayı tanıtan, temel beceriler ve deneyimler kazandıran bir müze olmuştur. Bu müze aynı zamanda çocuk müzeleri içinde en eski ikinci müzedir. Müze, çeşitli sergiler ve programlar düzenlemektedir. Çocukları eğlendirmeyi ve hayal gücünü ve oyunları kullanarak uygulamalı olarak öğretmeyi amaçlamaktadır. Boston Children's Museum'da oyuncak bebekler, Amerika tarihine ve farklı kültürlere ait objelerin koleksiyonu sergilenmektedir. Bu müze çocukluk eğitiminde oyunun kritik rolü ile ilgili öncü müzelerden biridir. ${ }^{25}$ Boston Children's Museum'un sergi ve düzenleme başkan yardımcısı Gail Ringel'a göre çocuklar, yetişkinlerin deneyim haznesi olarak daha az ve daha hareketli bir versiyonudur. ${ }^{26}$ Japonya hakkındaki sergileme alanında çocuklara Japonya'nın bazı geleneklerinin kendi kültürleriyle aynı, bazılarının farklı ve Japonya'da geleneğin önemli olduğu bilgisi verilmeye çalışılmaktadır.

23 Brooklyns Children's Museum, erişim 10 Eylül 2019, https://www.brooklynkids.org/exhibit/consectueturelit-sed-2/

24 Züheyla Aykut, "Müze sergileme Elemanlarında İzleyici- Sergi Etkileşimi Bağlamında Mekan Tasarımı,” 70.

25 Boston Childrens Museum Exhibits, erişim 11 Kasım 2019, https://www.bostonchildrensmuseum.org/exhibits-programs/exhibits?field_state_value=Current

26 Gail Ringel, “Designing Exhibits for Kids: What Are We Thinking?”, From Content to Play: Family-Oriented Interactive Spaces in Art and History Museums Symposium 4-5 June 2005 (J. Paul Getty Museum, Haziran 2005), 1, erişim 7 Nisan 2020, https://www.getty.edu/education/symposium/Ringel.pdf 
Tablo 2

Boston Çocuk Müzesi İç mekân Görünümü ve Japon evi bölümü (https://www.bostonchildrensmuseum.org/exhibits-programs/exhibits/japanese-house)

\begin{tabular}{|c|c|c|}
\hline Boston Children's Museum & Bölüm adı & Tanımları \\
\hline & Green Trail Bölümü & $\begin{array}{l}\text { Yeşil bina sertifikası olan müzede } \\
\text { bulunan Green Trail sergisinde, } \\
\text { müze binasını ve çevreyi çevre } \\
\text { dostu bir yer hâline getiren } \\
\text { yönlerini gösteren bilgilendirme } \\
\text { panosu yer almaktadır. }\end{array}$ \\
\hline & Japanese House & $\begin{array}{l}\text { Çocukların kardeş şehir ilişkileri } \\
\text { sebebiyle Kyoto'dan } 1979 \text { yılında } \\
\text { hediye edilen ve parçaları Boston } \\
\text { Children Museum'da tekrar } \\
\text { birleştirilen orijinal Japon evini } \\
\text { ziyaret edebildikleri ve kültürünü } \\
\text { tanıdıkları bir bölümdür. }\end{array}$ \\
\hline 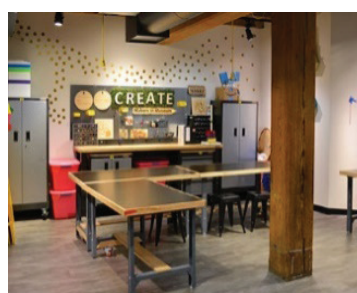 & Steam Laboratuvar1 & $\begin{array}{l}\text { Bilim, teknoloji ve yaratıcılığı } \\
\text { teşvik eden bir bölümdür. Robot } \\
\text { programlama, araç ve teknolojileri } \\
\text { denemek için hazırlanmıştır. } \\
\text { Araç gereçler için dolaplar ve } \\
\text { çocukların tasarımlarını yaparken } \\
\text { kullanabilecekleri masa ve } \\
\text { tabureler yerleştirilmiştir. }\end{array}$ \\
\hline
\end{tabular}

Sanat atölyesinde çocukları çeşitli deneylere teşvik eden ve çocukların bazı bilimsel süreçleri deneyimlemelerini sağlayan atölyeler bulunmakta, inşaat atölyesinde ise bizi her gün çevreleyen binalardan ilham alarak çocukların hayallerindeki şehri inşa etmesine imkan verilmektedir. Tablo 2'de gösterilen Japon evi bölümünde, kardeş şehir Kyoto'dan getirtilen geleneksel Japon evinde çocukların Japon kültürünü tanımaları ve Japon evinin içini de deneyimlemeleri sağlanmıştır. Diğer bir deyişle Japon aile hayatı, gelenekleri, sanatı ve törenleri çocuklar tarafından deneyimlenmektedir. (T. 2) Boston Children's Museum'da aileleriyle ya da öğretmenleri ile oynayarak öğrenme imkânı bulan çocuklar, bilim bahçesinde etkinlikler yapabilmekte ya da farklı kültürlere ait simgeleri etkileşimli olarak inceleyebilmektedir ${ }^{27}$.

27 Boston Children's Museum Exhibits and Programs, erişim 11 Kasım 2019 https://www.bostonchildrensmuseum.org/exhibits-programs/exhibits?field_state_value=Current 


\section{Tablo 3}

Canadian Children's Museum'dan iç mekân sergileme alanları, (https://www.historymuseum.ca/visit/childrens-museum/\#kids )

\begin{tabular}{|c|c|c|}
\hline Canadian Museum of History & Bölüm adı & Tanımları \\
\hline & Sahne alma bölümü & $\begin{array}{l}\text { Çocukların sahne } \\
\text { alabildikleri ve kostümleri } \\
\text { deneyebildikleri bir bölüm } \\
\text { oluşturulmuştur. }\end{array}$ \\
\hline & Tarihi mekânları tanıma & $\begin{array}{l}\text { Misır piramitlerini tanıtan } \\
\text { sergileme ünitesinde } \\
\text { çocuklar piramitlerin içinden } \\
\text { geçebilmektedir. }\end{array}$ \\
\hline & İnşa etme bölümü & $\begin{array}{l}\text { Çocukların bir yapı inşa } \\
\text { edebildikleri bir bölüm } \\
\text { oluşturulmuş ve farklı } \\
\text { ülkelerden yapıları } \\
\text { görebilecekleri dekor } \\
\text { tasarımları yerleştirilmiştir. }\end{array}$ \\
\hline
\end{tabular}

Canadian Museum of History'nin içerisinde bulunan Canadian Children's Museum'da çocukların tarihten bir karakteri canlandırabilecekleri, kostüm seçerek sahne alabilecekleri bir bölüm de tasarlanmıștır. Mısır piramitlerinin içine girebildikleri ve gizli bir geçit keşfedebildikleri kendi ölçülerinde tasarımlara ya da fark11 ülkelerdeki kültürleri yaşatabilecekleri mekânlara tabloda görüldüğü gibi işlevler verilmiştir. Kartpostal hazırlayıp göndermek için ve Pakistan’ı andıran mekânda otobüse tırmanma imkânı sunan bir bölüm de bulunmaktadır. Farklı kültürlerin müzik aletlerini çalabilecekleri ve onların trafik araçlarını kullanabilecekleri mekânlar tasarlanmıştır. Japon kültürüne ait giysilerin deneyebildikleri ve origami sanatı yapabildikleri bölüm de bulunmaktadır. Kukla yapabildikleri ve onunla gölge oyunu oynatabildikleri Hindistan'a ait tasarlanmış bir bölüm de vardır. Canadian Museum of History'nin çocuk müzesindeki çeşitlilik ile her yaştan çocuğa hitap etmektedir. Çocuklar, ülkelerin tarihini oyun yolu ile keşfetmektedirler. Çocuk müzesi, çocukların mekânda sergilenen ve deneyimleyebildikleri ürünler ile dünyayı dolaşmasına, hayatlarını zenginleştirmesine, oyuncak ve oyun çeşitliliği de dâhil olmak üzere ser- 
giler, kostümler, uygulamalı eşyalar ve eserler yoluyla diğer kültürleri keşfederek deneyimlerini genişletmesine olanak sağlamaktadır. Mekân içerisinde tarihi ve farklı ülkelerden mekânları canlandırarak deneysel bir yorumlama imkânı sağlamaktadır. Burada çocukların tarihten seçtikleri kahramanların kostümlerini giyerek ya da uzak ülkelerdeki mekânların kopyası olan kendi boyutlarındaki mimari simgelerin içerisine girerek aktif olarak öğrenmeleri sağlanmaktadır ${ }^{28}$.

\section{Tablo 4}

KidsQuest Museum iç mekân bölümleri, (https://www.kidsquestmuseum.org/exhibits/tot-orchard/\#8)

\begin{tabular}{|c|c|c|}
\hline KidsQuest Museum & Bölüm adı & Tanımları \\
\hline & $\begin{array}{l}\text { Ölçme tartma } \\
\text { bölümü }\end{array}$ & $\begin{array}{l}\text { A ğırlıklar ve ölçümler, } \\
\text { çocukların tartım ve } \\
\text { fiyatlandırma ile ilgili } \\
\text { matematiksel işlemler hakkında } \\
\text { bilgi edinmesine yardımcı olur. }\end{array}$ \\
\hline & Taşımacılık bölümü & $\begin{array}{l}\text { Go Gallery'de kutuları yukarı } \\
\text { ve aşağı hareket ettirerek } \\
\text { dikey ve yatay taşıyıcı } \\
\text { bantlar kullanarak kutuları } \\
\text { tartabilmekte daha sonra } \\
\text { transfer ederek, sonra kutuları } \\
\text { çeşitli oyun alanlarına toplayıp } \\
\text { gönderebilmektedirler. }\end{array}$ \\
\hline & Satış bölümü, & $\begin{array}{l}\text { Çocuklara kendi boyutlarında } \\
\text { satış birimleri oluşturulmuştur. }\end{array}$ \\
\hline & $\begin{array}{l}\text { Harita ve şehircilik } \\
\text { temalı bölüm }\end{array}$ & $\begin{array}{l}\text { Square Mile City Wall, dünyanın } \\
\text { dört bir yanının birkaç mil kare } \\
\text { için kuş bakışı görünümünü } \\
\text { gösterir. Mekânın duvarlarında } \\
\text { dijital ekranlar ve kent silüeti } \\
\text { kullanılmış, çocukların } \\
\text { boyutlarına uygun oturma } \\
\text { elemanları yerleştirilmiştir. }\end{array}$ \\
\hline & $\begin{array}{l}\text { Kütüphane bölümü, } \\
\text { Kids Quest Çocuk } \\
\text { Müzesi, Londra }\end{array}$ & $\begin{array}{l}\text { İç mekânında çocukların } \\
\text { ulaşabileceği yükseklikte } \\
\text { sergilenen kitaplar ve } \\
\text { bölümlere ayrılmış eğrisel } \\
\text { formlarda oturma elemanları } \\
\text { görülmektedir. }\end{array}$ \\
\hline
\end{tabular}

28 Canadian Museum of History, erişim 24 Ekim 2019, https://www.historymuseum.ca/visit/childrens-museum/ 
Tablo 4'te görülen bölümlerin dışında daha farklı ilgi alanlarına ve yaş gruplarına hitap eden birçok bölümü de bulunan Londra çocuk müzesinin 'Dress up station' bölümünde çocuklar hikâyedeki kahramanların kostümlerini giyerek hayal güçleri ile bu aksesuarları birleştirerek hikâyeyi canlandırabilmektedir² ${ }^{29}$.

\section{Türkiye'de Çocuklara Yönelik Tasarlanan Müzeler}

Türkiye'de müzelerin iç mekânları ve sergileme düzenleri koleksiyon toplama, koruma ve sergileme amaçlı kullanılmaktadır. Amerika ve Kanada gibi ülkelerde bulunan çocuk müzelerinde görülen eğitime dayalı ve uygulamanın ya da deneyimlemenin olduğu müze mekânları da yaygınlaşmaktadır ${ }^{30}$. Eğitim müzeleri, bilim merkezleri, çocuk sanatları müzeleri, çocuk oyunlarını sergileyen müzeler çocuk müzesi kapsamına girmemektedir ancak bu saydıklarımız çocuk müzelerine benzer, çocukları öncelikli hedef kitle olarak alan eğitim ve etkinlikler planlayan müzelerdir ${ }^{31}$.

Türkiye'de çocuklara yönelik tasarlanan müzeler arasında Kartal Masal Müzesi, Düşstepe Oyun Müzesi ve Atatürk ve Çocuk müzesi gibi müzeler bulunmaktadır. Edirne'de bulunan Hasan Ali Yücel Çocuk Müzesi interaktif müze anlayışını benimsemiş ve müzede tarih ile ilgili objeler sergilenmektedir. Evrensel Çocuk Müzesi İzmir'de kurulmuştur. Burada bilim ve tarihle ilgili çocuklara yönelik etkileșimli sergileme alanları oluşturulmuştur. Çocukları eğitim ve bilimle buluşturmayı hedefleyen bu müze içerisinde paleontoloji ${ }^{32}$ sergisi, entomoloji sergisi, inşaat adası, bilim adası tasarlanmıştır. İzmir'de bulunan Karşlyaka Evrensel Çocuk Müzesi'nde arkeoloji ve nesli tükenmiş olan hayvanların benzerleri sergilenmektedir. Yayınlanan belgeseller, sinema ve gösteriler için de sahne bulunmaktadır. Eğitim, bilim ve eğlencenin birlikte yer alması planlanmıştır. Fosil kazı alanı ve entomoloji alanında böcek replikaları gösterilmektedir. Çocukların boyutlarına göre küçültülmüş iş makinaları ve eğitim alanları da bulunmaktadır. Çocukların yaşayarak, bilim ve eğlenceyi bir araya getirerek öğrenecekleri bir mekân oluşturulması hedeflenmiştir ${ }^{33}$. Çocukların dokunabilecekleri sergilemeler oluşturulan bu müzelerde sessiz olma ve dokunmama kuralı yerine, keşfetme öne çıkmaktadır. ${ }^{34}$ Oyun ile öğrenen çocuklar için müzelerde kendi boyutlarına göre tasarlanmış iç mekân donatı elemanları ile kendilerine daha yakın hissetmeleri sağlanmaktadır.

29 KidsQuest Museum, erişim 12 Kasım 2019, https://www.kidsquestmuseum.org/exhibits/tot-orchard/\#8

30 Kadriye Akmehmet Tezcan, "Müzelerin Eğitim Amaçlı Kullanımı Projesi”, Eğitim ve Müze Semineri (Ankara: Kök Yayıncılık, 2007), 175.

31 Karadeniz, "Dünyada Çocuk Müzeleri ile Bilim, Teknoloji ve Keșif Merkezlerinin İncelenmesi ve Türkiye İçin Bir Çocuk Müzesi Modeli Oluşturulması," 57.

32 Paleontoloji ya da diğer adıyla fosil bilim: fosilleri veri olarak kullanmakta olan ve dünyada yaşamın tarihini yazmak amacını taşıyan bilim dalıdır.

33 “Evrensel Çocuk Müzesi’nde Paleontoloji Adası Hazır”, Arkeolojik Haber, erișim 2 Kasım 2019. https:// www.arkeolojikhaber.com/haber-evrensel-cocuk-muzesinde-paleontoloji-adasi-hazir-4043/

34 Ömer Adıgüzel, "Okul Dışında Farklı Bir Öğrenme Ortamı Olarak Çocuk Müzeleri,” Eğitim Bilim Toplum 14 (2006), 33. 


\section{Atatürk ve Çocuk Müzesi}

Çalışmaya konu olan Atatürk ve Çocuk Müzesi, Yalova'da bulunmaktadır. Müze, “Tetrazon Yapı Tasarım ve Prodüksiyon” firması tarafından Yalova İl Kültür ve Turizm Müdürlüğü adına tasarlanmış bir müzedir. ${ }^{35}$ Tasarımcısı olan mimarlık ofisinden alınan bilgiye göre; müze, çocuk müzesi olarak tasarlanmamış ancak birinci hedef kitle olarak çocuklar düşünülmüştür. İç mekânda kullanılan sergileme elemanlarının etkileşimsel, hedef kitle grubu olan çocuklar için ergonomik ve dikkat çekici olmasına dikkat edilmiştir. Aktarmak istenilen bilgilerin "keşfedilmesi" ile müzelerde genel olarak uygulanan "objelere dokunma yasağı” yaklaşımının aksine, dokunma ve kullanma opsiyonlarını sunmak istemişlerdir. ${ }^{36}$

Etkileşimli sergileme elemanları bulunduran Atatürk ve Çocuk Müzesi, 19. Yüzyıl sonlarında yapılmış ve Mustafa Kemal Atatürk tarafından kullanılmış olan yapıda kurulmuştur. Atatürk'ün Yalova' da bulunan Yürüyen Köşk'ün inşa edilmesinden önce kullandığı yapı, iki katlı ve karkas bir yapıdır. Eski adı ile Baltacı Çiftliği Köşkü olarak bilinmektedir. Atatürk, bu çiftliği 10 Aralık 1929 yılında Türk hayvancılığına ve ziraatına örnek ürünler yetiştirmek amacıyla satın almıştır. ${ }^{37}$

Yap1, günümüzde Atatürk Tarımsal Araştırmalar Merkezi arazisinde ve mülkiyetinde bulunmaktadır. Atatürk bu çiftliği satın aldığı zaman köşk bu arazide bulunmaktaydı. İki katlı yapının giriş katında bir salon ve tuvalet bulunmakta, üst kata ise merdiven ile ulaşılarak diğer salona girilmektedir. ${ }^{38}$ Yap1, 1981 yılında restore edilerek Atatürk ile ilgili eşyaların sergilendiği bir müze olarak kullanılmıştır. 20 Ağustos 2014 tarihinde Atatürk ve Çocuk Müzesi, ilköğretim çocuklarına yönelik modern müze anlayışı ile yeniden tasarlanmıştır ${ }^{39}$. Ziyaretçilerin müze içindeki dolaşımı, salonlara ayrı konseptler vererek sağlanmış ve bu konseptlere uygun sergilemeler oluşturulmuştur. Sergi odalarına isim verilerek anlatılmak istenilen konuya uygun bilgilendirme panoları ve tarihi nesneler yerleştirilmiştir. Müzede video gösterimleri de yapılmaktadır. Müzelerde aydınlatma doğal ve yapay olarak iki bölümde incelenmektedir. Atatürk ve Çocuk Müzesi'nin aydınlatılmasında doğal ışık etkin olarak kullanılmaktadır. Giriş katında sergileme bölümlerinde altı adet pencere, ikinci katta ise beş adet pencere bulunmaktadır. Bunun dışında bilgilendirme panolarının bazılarının içinde gizli aydınlatmalar kullanılarak şeffaf bir etki sağlanmıştır.

35 Yalova İl Kültür ve Turizm Müdürlüğünden alınan bilgiye göre müzenin adının yakın zamanda değiştirilmesi planlanmaktadır (10.04.2020 tarihli görüşme).

36 10.04.2020 tarihinde Tetrazon tasarım ofisinden Burçak Madran ile yapılan yazılı görüşmede bu bilgilere ulaşılmıştır.

37 Nazmi Kal, “Atatürk Çiftlikleri,” Ekonomik Forum Dergisi 265 (2016), 105.

38 Selçuk Seçkin, “Atatürk Döneminde Yalova'da Yapılan İmar Uygulamaları," Uluslararası Ahmet Yesevi'den Günümüze İnsanlığa Yön Veren Türk Büyükleri Sempozyumu Bildirileri, Romanya-Köstence 03-07 Eylül 2008, Haz. İrfan Ünver Nasrattınoğlu (Ankara: Halk Kültürü Araştırmaları Kurumu Yayınları, 2009), 79.

39 Yalova Kent Müzesi, erişim 10 Eylül 2019, http://yalovakentmuzesi.gov.tr/turizm/tigem-ataturk-ve-cocukmuzesi/ 
İki katlı yapının giriş katında karşılama bölümünde Yalova'da görülmesi gereken yerler ile ilgili zeminde bir grafik tasarım bulunmaktadır. Mekânda sergileme elemanlarında turuncu ve mavi renk ve tonları kullanılmıştır. Etkileşimli sergileme elemanları ile videoların bulunduğu sergileme üniteleri yerleştirilmiş; A tatürk ve manevi çocukları ve Atatürk'ün eğitim ile ilgili yapmış olduğu çalışmalar hakkında bilgilendirici panolar tasarlanmıştır. Müzenin giriş katında yarı saydam sergileme elemanı ile Atatürk'ün 'Çoban Mustafa' isimli çocukla karşıllaşması betimlenmiştir.

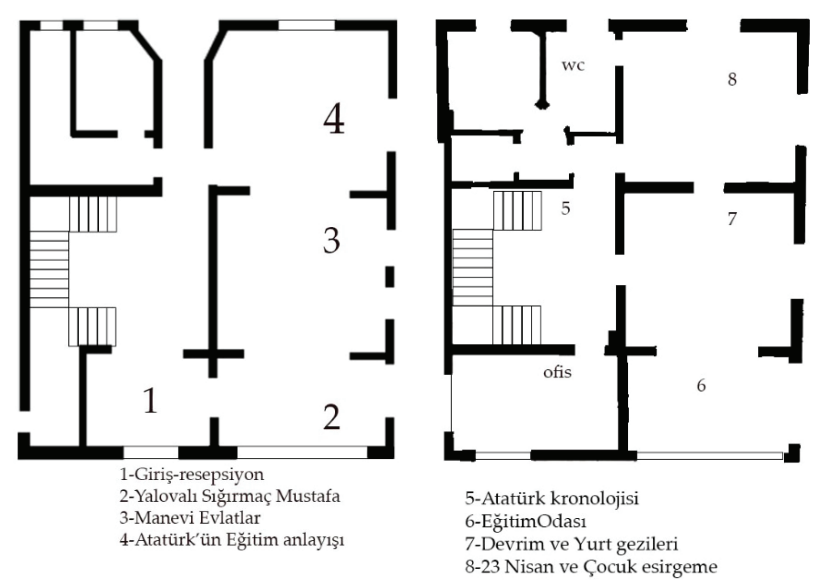

G. 1. Atatürk ve Çocuk Müzesi Krokisi (Hülya Yavuz Öden, 2020)

Atatürk ve Çocuk Müzesi'nin krokide görülen bir numaralı bölümünde giriş ve resepsiyon bankosu bulunmaktadır. Bu banko girişte sol taraftadır. Bir numaralı bölümden iki numaralı odaya girildiğinde Yalovalı Sığırtmaç Mustafa ile ilgili bilgiler ve yarı saydam resimler mekânın orta bölümünde sergilenmektedir ve bir kiosk yerleştirilmiştir. Krokide görülen üç numaralı bölüme girildiğinde ise Atatürk'ün manevi evlatları ile ilgili bilgilerin verildiği sergileme ünitesi duvarda görülmektedir. Giriş katındaki dördüncü bölümde Atatürk'ün eğitim anlayışı ile ilgili bilgiler mekânın ortasına yerleştirilen ve duvarda tasarlanan sergileme ünitelerinde bulunmaktadır. İkinci katta ise ofis, sergileme alanları, eğitim odası ve tuvalet yer almaktadır. İkinci katta beşinci bölümde Atatürk Kronolojisi, altıncı bölümde eğitim odası, yedinci bölümde devrim ve yurt gezileri, sekizinci bölümde ise 23 Nisan Çocuk Bayramı ile ilgili sergileme elemanları bulunmaktadır. 23 Nisan Salonu'nda, çocukların Atatürk ile fotoğraf çekilebilecekleri bir köşe tasarlanmıştır. Yalova'ya ait 23 Nisan Egemenlik ve Çocuk Bayramı fotoğrafları dijital olarak gösterilmektedir (G. 1.). 


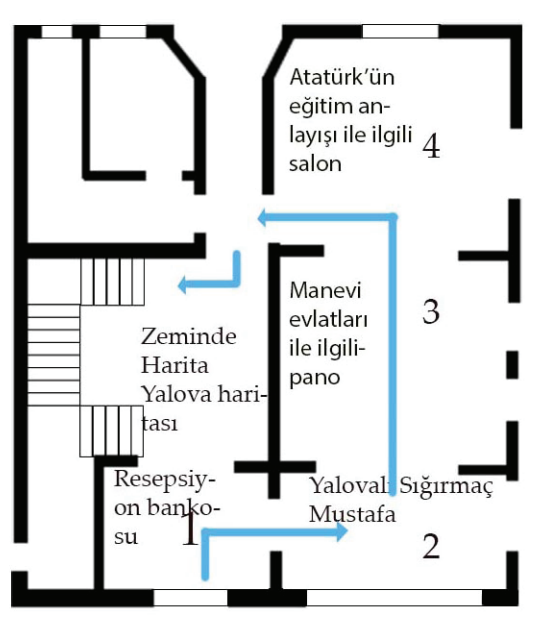

Giriş katı yönlendirme

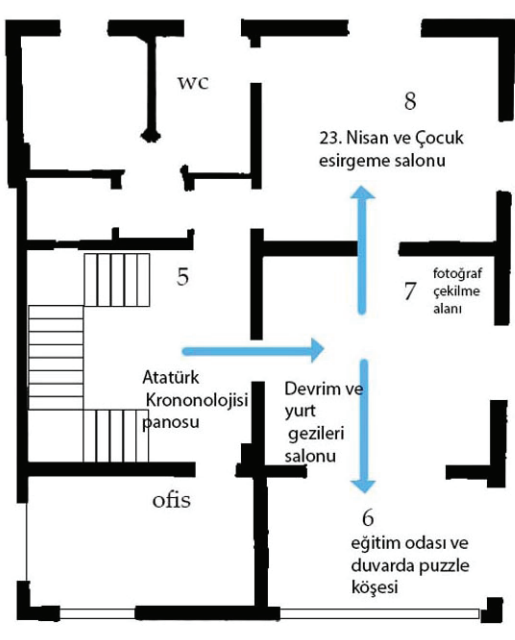

Üst kat yönlendirme

G. 2. Atatürk ve Çocuk Müzesi Dolaşım Şeması (Hülya Yavuz Öden, 2020)

Atatürk ve Çocuk Müzesi iç mekânında dolaşım ve yönlendirmeler resepsiyondan başlamaktadır. Çocuklar, 2 numaralı odada Yalovalı Sığırtmaç Mustafa bölümü, 3 numaralı odada manevi evlatları ile ilgili etkileşimli pano, 4 numaralı odada Atatürk'ün eğitim anlayışı ile ilgili bölüm ve daha sonra üst kata yönlendirilmektedir. Üst katta ise merdivenlerin karşısında Atatürk kronolojisi panosu, 7 numarada Devrim ve Yurt Gezileri bölümü, bu bölümün ortasında Türkiye haritası içerisinde dijital ekran olan sergileme elemanı ve pencerenin bulunduğu köşede Atatürk görseli ile fotoraf köşesi bulunmaktadır. 7 . bölümden 8 . bölüme ve eğitim odasına geçiş bulunmaktadır. $\mathrm{Bu}$ katta ayrıca wc ve ofis yer almaktadır (G. 2).
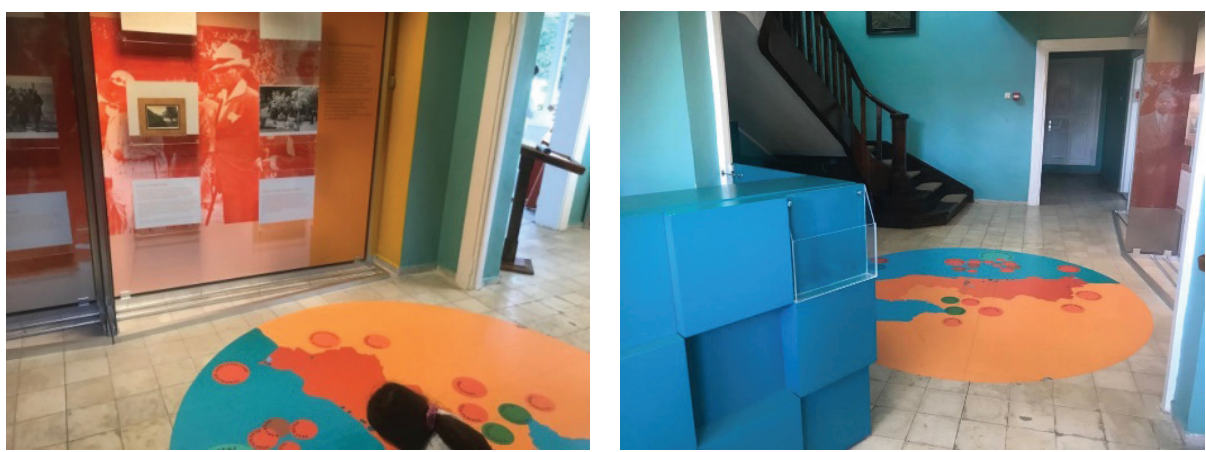

G. 3. Atatürk ve Çocuk Müzesi giriş katı ve resepsiyon bankosu görünümü (Hülya Yavuz Öden, 2019)

Giriş bölümünde bulunan resepsiyon bankosunda mavi renk kullanılmıştır. Mekânın genelinde kullanılan kübik formlar, girinti ve çıkıntılarla hareketli bir görünüm vermektedir. Girişte bir numaralı bölüm ile merdivenler arasındaki mekânda 
zeminde mekândaki diğer elemanlar ile bütünlük sağlayan renkli Yalova haritası uygulanmış ve şehirde bulunan önemli mekânlar işaretlenmiştir. Bu harita görseli, zemindeki karo döşemenin üzerine uygulanmıştır. Çocukların zeminde üzerindeki daireler ile mekânların isimlerini görebilmeleri sağlanmıştır (G. 3).
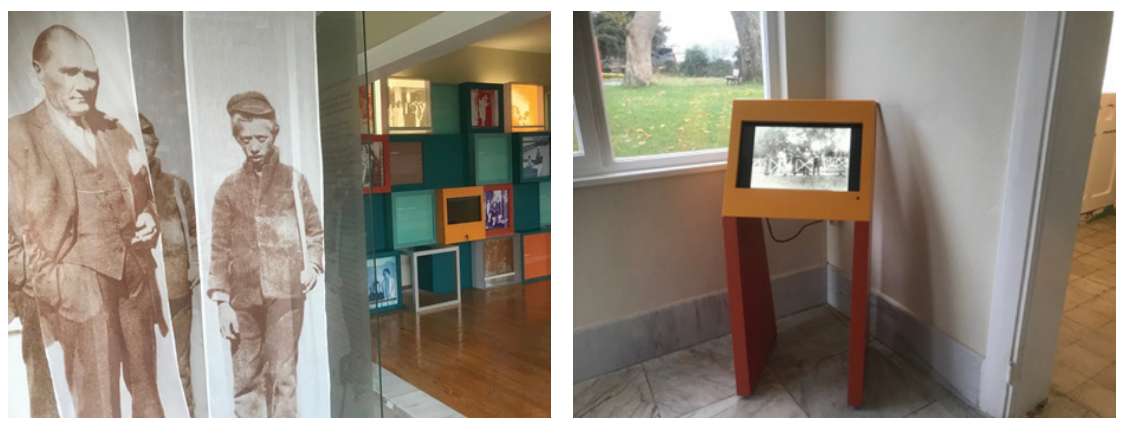

G. 4. Müzenin giriş katında bulunan farklı derinliklerde sergileme elemanları ve yarı saydam fotoğraf sergilemesi; Yalovalı Sığırtmaç Mustafa Bölümü (Hülya Yavuz Öden, 2019)

Müzenin giriş katında iki numaralı bölümde kiosk sistemi kullanılmıştır. Giriş katında krokide üç numaralı odada Atatürk'ün manevi çocukları ile bilgiler içeren panolar bulunmaktadır. Atatürk Çocuk Müzesi’nde sergileme üniteleri, ilköğretim çağındaki çocukların Atatürk ve manevi çocukları ile ilgili metinleri okuyacağı ve interaktif pano ile öğrenmeleri amacı ile tasarlanmıştır. Bu panolarda çocuklara müze görevlileri ya da öğretmenleri tarafından o yıllarla ilgili sorular sorulmakta ve öğrencilerden cevap beklenmektedir. Daha sonra sergileme ünitesindeki kapaklar açıldığında, kapakta yazan yılda hangi önemli olayın olduğu ile ilgili metinler karşılarına çıkmaktadır. ${ }^{40}$ Sergileme elemanları aynı yüzey üzerinde farklı derinliklerde ve renklerde kullanılmıştır. Genellikle turuncu ve mavinin tonlarının egemen olduğu odada bazı ünitelerin kapaklarının içerisinde belirtilen yılda gerçekleşen önemli olaylar hakkında bilgiler bulunmaktadır. Ünitelerin bir kısmı kapaklı diğer kısmı sabit pano şeklinde tasarlanmıştır. (G. 4)
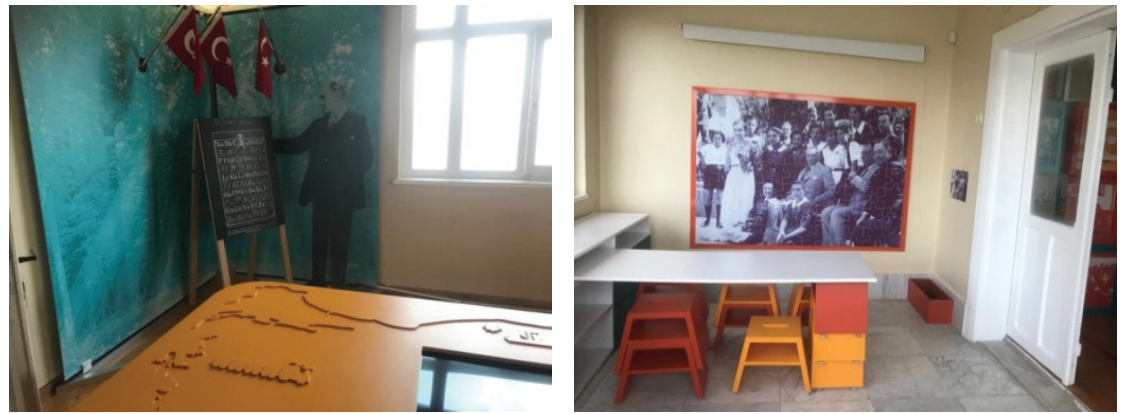

G. 5. Atatürk'ün yazı tahtasında harfleri göstermesi ile ilgili pano ve Yapboz panosu; eğitim bölümü (Hülya Yavuz Öden, 2019)

40 11.12.2019 tarihinde müze görevlisi ile etkileşimli sergilemelerle ilgili görüşmede bilgi edinilmiştir. 
Videoların gösterilmekte olduğu, turuncu tonlarının kullanıldığ1 sergileme elemanı da G. 5 'te görülmektedir. Aynı zamanda Atatürk'ün eğitime verdiği önemi de vurgulamak amacı ile kara tahta önündeki fotoğrafı iki boyutlu ve şeffaf olarak sergilenmektedir. Bu panonun olduğu bölüm, krokide yedinci bölümdür. İkinci katta bulunan krokide altıncı bölümde görülen eğitim mekânında çocukların boyama etkinliği yapabildiği sarı ve turuncu renklerde oturma elemanları, masanın olduğu bölümde ise duvarda bir yapboz bulunmaktadır. Çocuklar bu büyük yapbozu tamamlayarak Atatürk ve çocuklarla olan fotoğrafını deneyimleyerek öğrenmedi hedeflenmiştir (G. 5).

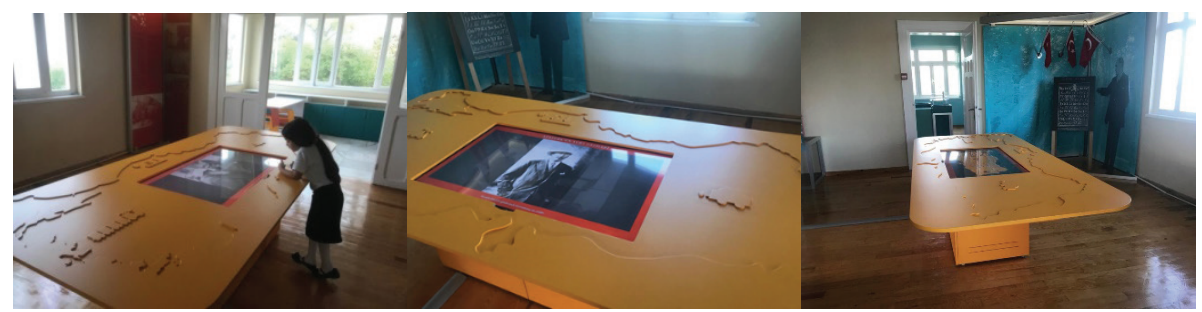

G. 6. Devrimler ve yurt gezileri bölümü Türkiye haritası ve dijital sunum ekranı içeren sergileme elemanı (Hülya Yavuz Öden, 2019)

İkinci katın orta bölümünde, krokide yedinci bölümde bulunan devrimler ve yurt gezileri bölümünde, yatay düzlemde Türkiye haritası panosu, aynı zamanda Atatürk ile ilgili videoların gösterildiği bir ekran bulunmaktadır. Bu düzlem kübik formda bir ayak üzerindedir. Türkiye haritası tek renk üzerine çizgisel olarak uygulanmıştır ve orta kısmında bulunan ekranda Atatürk'ün hayatı ile ilgili belgesel gösterilmektedir. Üzerindeki kabartma Türkiye haritasının içinde bir otomobil ve tren figürü uygulanmıştır (G. 6). Sergileme elemanlarında keskin köşeler kullanılmamıştır. Bu sergileme elemanı mekânın ortasında konumlandırılmıştır.

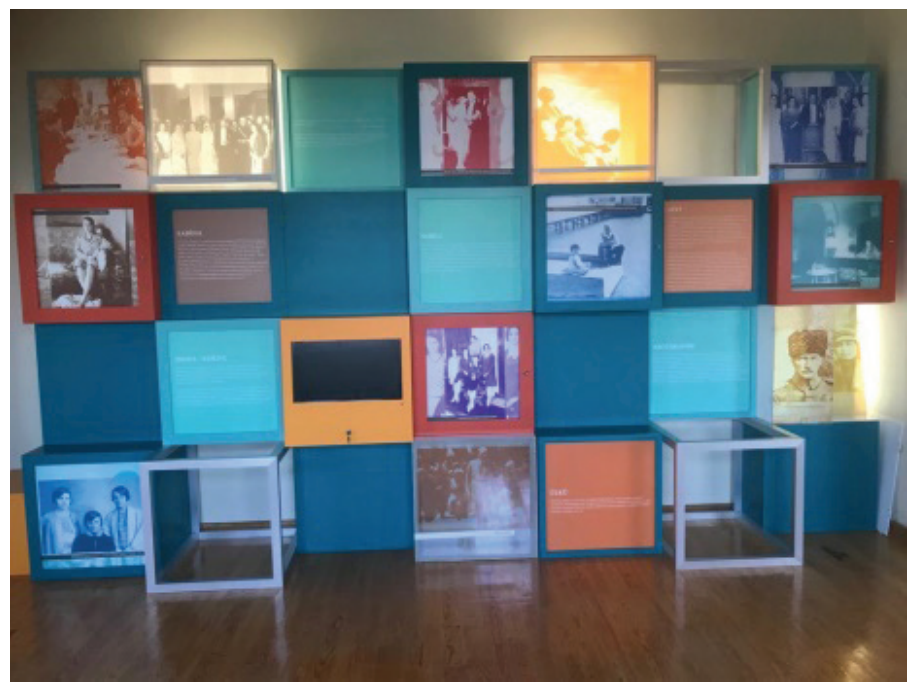

G. 7. Atatürk’ün manevi çocukları bilgilendirme panoları (Hülya Yavuz Öden, 2019) 
Giriş bölümünde yer alan Atatürk'ün manevi evlatlarıyla ilgili bilgilerin bulunduğu sergileme elemanı renkli kutulardan oluşmaktadır. Mavi ve turuncunun zıtlığından yararlanılmıştır. Çerçeveler içerisine tarihi fotoğraflar yerleştirilmiştir. Bazı bilgilendirme kutuları yarı saydam olarak ve aydınlatma ile donatılmış, bazıları da kapakları açılarak içerisindeki bilgilere ulaşılabilir olarak hareketli tasarlanmıştır. Etkileşimli modüller bu bölümde kullanılmıştır. Bu modüllerde Atatürk'ün yedi manevi evladının eğitimleri hakkında bilgiler verilmektedir (G. 7).
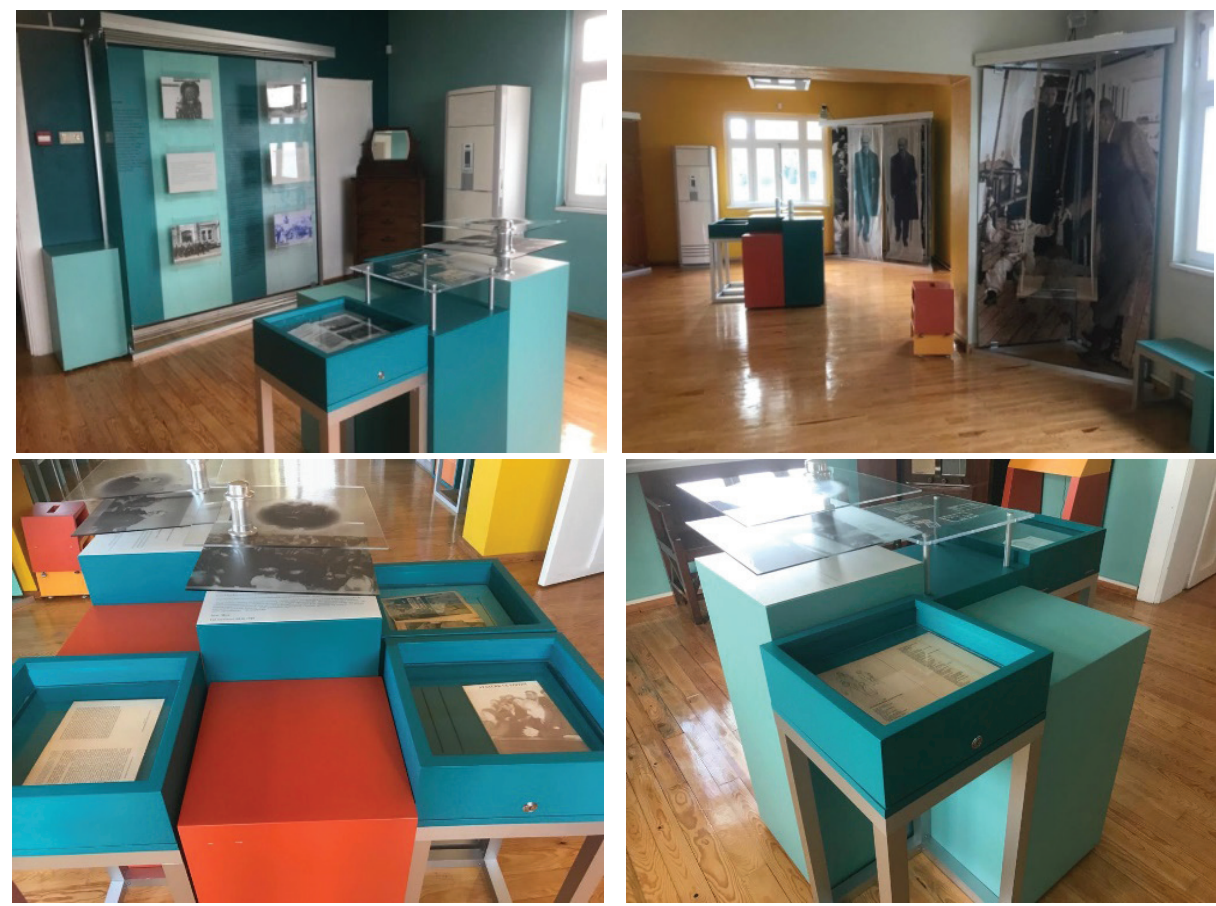

G. 8. Yatay vitrin içi sergileme elemanları ve Atatürk ve Çocuk Müzesi genel görünüm (Hülya Yavuz Öden, 2019)

Bu bölümün ortasında vitrin içi sergileme kullanılmıştır. Vitrin içi sergilemeler, küp şeklinde üstü camla kaplanmış içinde bulunan objenin zarar görmesine engel olmak için uygulanan sunum tekniğidir. Bu vitrinlerin yüksekliği ziyaretçilerin yaş grubuna göre ayarlanmalıdır. Atatürk ve Çocuk Müzesi'nde vitrin içi sergilemelerde pullar, kitaplar ve fotoğraflar yerleştirilmiştir.

Vitrin içi sergileme elemanları çocukların okumak için ulaşabileceği yükseklikte (kendi içinde farklı yüksekliklerde), şeffaf ve mavi tonlarının kullanıldığı elemanlar olarak tasarlanmıştır. Atatürk ve bir salıncağın olduğu fotoğraf ile bütünleşmiş olan bölümde salıncakta sallanan saydam bir çocuk figürü yerleştirilmiştir (G. 8). Mekânın ortasında konumlandırılmış farklı yüksekliklerde sergileme elemanlarının şeffaf bölümlerinde çocukların ve ailelerin incelemesi için Atatürk'ün manevi çocukları ile 
ilgili hatıralar sergilenmektedir. Mekânların arasında farklı konseptlere bölünen iç mekân odaları renk farklılıkları kullanarak birbirinden ayrıştırılmıştır.
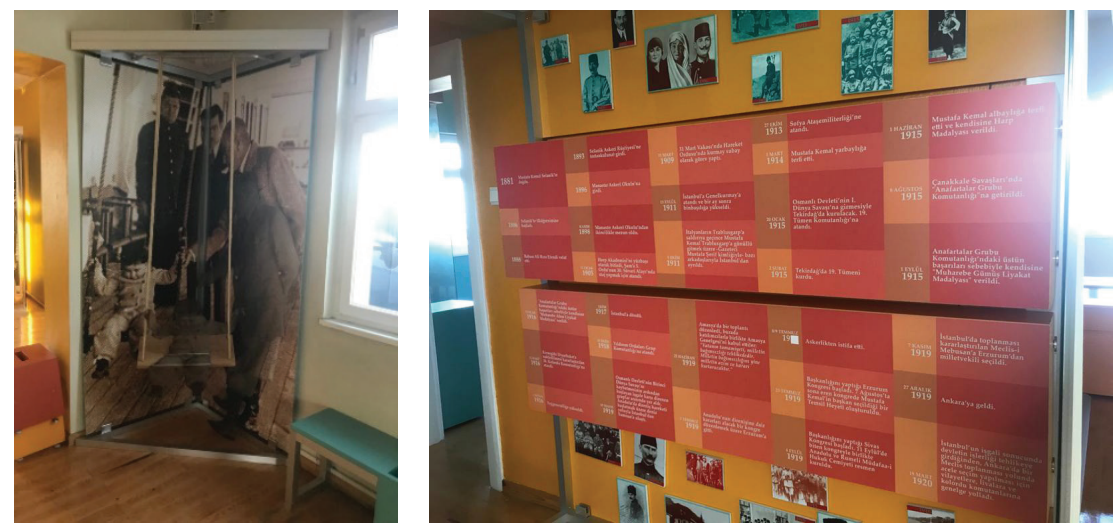

G. 9. İkinci kat giriș bölümünde Atatürk Kronolojisi panosu ve Atatürk görseli ile fotoğraf bölümü (Hülya Yavuz Öden, 2019)

İkinci kata ulaşıldığında merdivenlerin karşısında krokide 5 numaralı bölümde Atatürk Kronolojisi panosu görülmektedir. Atatürk fotoğraflarına panonun üst ve alt sarı bölümlerinde; kronolojik bilgiler ise dikdörtgen formunda panoda orta bölümünde göz hizasında yer almaktadır (G. 9).

\section{Sonuç}

Brooklyn Childrens Museum, Boston Childrens Museum, Canadian Children's Museum ve Londra KidsQuest Museum gibi çocuklara yönelik tasarlanmış müzelerde iç mekânda bulunan sergileme elemanlarını incelediğimizde, vitrin içi sergileme elemanlarının bazı özel koleksiyon bölümlerinde kullanıldığı ancak müzenin büyük çoğunluğunda çocukların dokunabilecekleri sergilemeler ve oyunla etkileşimde bulunabilecekleri mekânlar tasarlandığı görülmektedir. Etkileşimli müze anlayış1 Türkiye'de Atatürk ve Çocuk Müzesi, Karşıyaka Evrensel Çocuk Müzesi gibi örneklerde görülmektedir. Bu müzelerde çocuklar hedef kitle olarak alınmıştır. Çocukların okul dışında farklı bir mekânda eğitim görmesi ve bilginin kalıcı olması amacıyla etkileşimli çocuk müzelerinin oluşturulması gerekmektedir. Tarih müzelerinin, bilim müzelerinin içerisinde ya da çocukların kendi boyutlarında tasarlanmış, oynayarak öğrenebilecekleri sergileme elemanları ile farklı alanlardaki müzeler çocuklara ve ailelerine yönelik etkin mekânlardır. Çocuklara yönelik tasarım ve grafik düzenlemeleri ile çocukların tarihi ya da sergilenen objeleri deneyimleyebilecekleri iç mekânlar oluşturulması gerekmektedir. Çocuklar öğrenmeleri için dokunsal ve görsel deneyimlere ihtiyaç duymaktadır. Bu sebeple çocuk müzelerindeki deneyimler ile hayal gücünü kullanması ve müzede edindiği bilgilerle hayatı daha kolay bağdaştırması amaçlanmaktadır. Çocukların gelişim süreçlerinde ve eğitimlerinde önemli bir yer kaplayan 
bu deneyimler, Türkiye'de bu müzelerin daha fazla sayısının artmasının gerekliliğini göstermektedir. Yaratıcılığı destekleyen mekânların bireylerin yenilikçi yönlerini ortaya çıkarmaya yardımcı olmasından dolayı, çocuk müzeleri de çocukların oyun oynayabildiği ve öğrenebildiği mekânlar olarak tasarlanmalıdır. Atatürk ve Çocuk Müzesi örneğinde olduğu gibi çocuk müzesi olarak tasarlanmasa da özellikle ilköğretim çağındaki çocukları öncelikli hedef kitle almış olan müzelerde dokunarak ve etkileşimde bulunarak kalıcı bilgiler edinilebilmektedir. Atatürk ve Çocuk Müzesi'nde klasik müze sergilemelerinin dışında bir sergileme yöntemi kullanılmıştır. Vitrin içi sergilemeler ve kioskların dışında diğer sergileme ünitelerinde, alışılmış pano düzeninin dışına çıkarak kutular oluşturulmuş ve içinde bilgi gizlenen ve etkileşimli öğrenme yöntemi uygulanmıştır. Açılır kapaklı üniteler ve görsellerin yarı saydam kullanıldığı bölümler, farklı bir sergileme yöntemi uygulanması bakımından önemlidir. Mekânın odaları belirli konseptlere ayrılmıştır. Atatürk ve Çocuk Müzesi'nin iç mekân tasarımı ve sergileme elemanlarında çocukların ilgisini çekecek renkler ve hareketli formlar kullanılmıştır. Diğer çocuklara yönelik tasarlanmış müzelerde olduğu gibi burada da sergileme elemanlarının boyutları çocukların ulaşabileceği yüksekliklerde tasarlanmıştır. Öğretici sergilemeler, Atatürk ve Çocuk Müzesi'nde zeminde oluşturulan harita gibi yönlendirme ve iç mekân düzenlemeleriyle etkileşimli müze tasarımı sağlanabilmektedir. Türkiye'de çocukların kendi boyutlarında sergileme elemanlarının bulunduğu, etkileşimli sergilemenin uygulandığı müze örneklerinin sayısının artması eğitimde ve kaliteli zaman geçirme de önemli bir etki oluşturacaktır. Bu müzelerin sergileme alanlarında görüldüğü gibi durağan ve dinamik sergileme tekniklerinin uygulanmasıyla çocukların dikkatleri daha fazla süre aktif tutulabilecektir. Atatürk ve Çocuk Müzesi'nde yer alan bilgilendirme panosunda olduğu gibi sorunun sergileme ünitesinin kapağında, cevabın ise ünitenin içerisinde olduğu anlatımlarla müze görevlisi ile etkileşimli öğrenme uygulanabilmektedir. Dokunarak ve uygulayarak öğrenme sistemi çocuklara yönelik tasarlanan müzelerde uygulanması gereken bir sistemdir. Çocuklara yönelik açılması planlanan müzelerde, teknolojinin faydalı yönlerinin, araştırmaya ve bilgi edinmeye yönelik dijital kaideler ve video sunumlarının kullanılması küçük yaştaki çocukların kültürel gelişimlerinde faydalı olacaktır.

Hakem Değerlendirmesi: Dıș bağımsız.

Çıkar Çatışması: Yazar çıkar çatışması bildirmemiştir.

Finansal Destek: Yazar bu çalıșma için finansal destek almadığını beyan etmiștir.

Peer-review: Externally peer-reviewed.

Conflict of Interest: The author has no conflict of interest to declare.

Grant Support: The author declared that this study has received no financial support 


\section{Kaynakça/References}

Adıgüzel, Ömer. “Okul Dışında Farklı Bir Öğrenme Ortamı Olarak Çocuk Müzeleri.” Eğitim Bilim Toplum 14 (2006): 32-41.

Aktaş Arnas, Yaşare. “Oyun, Öğrenme ve Deneyimin Birleşimi: Çocuk Müzeleri.” Yaratıcı Drama Dergisi 2 (2017): 17-30.

Aykut, Züheyla. "Müze Sergileme Elemanlarında İzleyici- Sergi Etkileşimi Bağlamında Mekân Tasarımı.” Yüksek Lisans Tezi, Marmara Üniversitesi, 2017.

Buyurgan, Serap. "Yaşayan ve Yaşatan Müze.” Yaratıcı Drama Dergisi 2 (2017): 127-136.

Filova, Natalia. "Human Centered Design of a Children's Museum." SWS Journal of Social Sciences and Art 2(2019): 67-80.

Göğebakan, Yüksel. “Alternatif Öğrenme Mekânları Olarak Müzelerin Eğitim-Öğretimde Kullanılmasının Önemi.” Atatürk Üniversitesi Güzel Sanatlar Enstitüsü Dergisi 40 (2018): 9-41.

Kal, Nazmi. “Atatürk Çiftlikleri.” Ekonomik Forum Dergisi 265 (2016): 100-105.

Kandemir, Özge ve Uçar Özlem. "Değişen Müze Kavramı ve Çağdaş Müze Mekânlarının Oluşturulmasına Yönelik Tasarım Girdileri.” Sanat ve Tasarım Dergisi 5 (2015): 17-47.

Karadeniz, Ceren. "Dünyada Çocuk Müzeleri ile Bilim, Teknoloji ve Keşif Merkezlerinin İncelenmesi ve Türkiye İçin Bir Çocuk Müzesi Modeli Oluşturulması.” Yüksek Lisans Tezi, Ankara Üniversitesi, 2009.

Karadeniz, Ceren. “Avrupa'da Çocuk Müzeleri: Frankfurt ve Hamburg Örneği.” Folklor/Edebiyat Dergisi 63 (2010): 169-178.

Kazova, Mehmet Can. "Çocuk Müzesi ve Bilim Merkezlerindeki İç Mekân Standartları ve Tasarım Yaklaşımları.” Yüksek Lisans Tezi, Başkent Üniversitesi, 2019.

Kılıçoğlu Arslan, Emine, Nursena Çarkacı, Büşra Kadıŏglu ve Meryem Çetingül. "Dünya Ülkelerinde ve Türkiye'de Çocuk Müzelerine Bir Bakış.” Çocuk ve Gelişim Dergisi 3 (2019): 45-64.

“Müze.” Grandmaster Genel Kültür Ansiklopedisi. 4. İstanbul: Milliyet Yayınlar1, 1992, 989-990.

Özsoy, Vedat ve Levent Mercin. "Sanat (Resim) Eğitiminde Müzelerin Kullanılmasında ilgili Kurum ve Kuruluşların Karşılıklı Görev ve Yükümlülükleri.” Türk Eğitim Bilimleri Dergisi 3 (Eylül 2003), [303-318]. Erişim 10 Nisan 2020. https://dergipark.org.tr/tr/pub/tebd/issue/26131/275245

Ringel, Gail. "Designing Exhibits for Kids: What Are We Thinking?". From Content to Play: Family-Oriented Interactive Spaces in Art and History Museums Symposium 4-5 June 2005. 1-9. Erişim 7 Nisan 2020. https://www.getty.edu/education/symposium/Ringel.pdf

Seçkin, Selçuk. “Atatürk Döneminde Yalova'da Yapılan İmar Uygulamaları.” Uluslararası Ahmet Yesevi’den Günümüze İnsanliğa Yön Veren Türk Büyükleri Sempozyumu Bildirileri, RomanyaKöstence 03-07 Eylül 2008. Haz. İrfan Ünver Nasrattınoğlu. Ankara: Halk Kültürü Araştırmaları Kurumu Yayınları 1, 2009, 76-82.

Shabbar, Nihad. “Çocuklar İçin Müze Eğitimi.” Kent Toplum Müze Deneyimler- Katkılar. İstanbul: Türkiye Ekonomik ve Toplumsal Tarih Vakfı Yayınları, 2001, 68-73.

S1lav, Muna. "Museums For Children". Procedia Social and Behavioral Sciences 122 (March 2014): 357-361. Erişim 20 Nisan 2020. https://doi.org/10.1016/j.sbspro.2014.01.1354

Studart, Denise Coelho. "The Perceptions and Behaviour of Children and Their Families in ChildOrientated Museum Exhibitions.” PhD Thesis, University College London, 2000. 
Tezcan Akmehmet, Kadriye. "Müzelerin Eğitim Amaçlı Kullanımı Projesi”. Uluslararası Katılımlı Eğitim ve Müze Semineri. Ankara: Kök Yayıncılık, 2007, 175-188.

Tezcan Akmehmet, Kadriye. "An Analysis of the Concept of Living Museum”. Yaratıcı Drama Dergisi 12 (2017): 1-16.

“Evrensel Çocuk Müzesi'nde paleontoloji adası hazır.” Erişim 2 Kasım 2019. https://www.arkeolojikhaber.com/haber-evrensel-cocuk-muzesinde-paleontoloji-adasi-hazir-4043/

Boston Children's Museum Exhibits and Programs. Erişim 11 Kasım 2019. https://www.bostonchildrensmuseum.org/exhibits-programs/exhibits?field_state_value $=$ Current

https://www.bostonchildrensmuseum.org/exhibits-programs/exhibits/japanese-house. Erişim 11 Kasım 2019.

Brooklyns Children's Museum. Erişim 10 Eylül 2019. https://www.brooklynkids.org/.

https://www.brooklynkids.org/exhibit/consectuetur-elit-sed-2/. Erişim 10 Eylül 2019.

Canadian Museum of History. Erişim 24 Ekim 2019. www.historymuseum.ca/visit/childrens-museum/

Find a Children's Museum. “About Children’s Museums.” Erișim 23 Nisan 2020. https://findachildrensmuseum.org/about/

KidsQuest Museum. Erişim 12 Kasım 2019. https://www.kidsquestmuseum.org/exhibits/totorchard/\#8

Yalova Kent Müzesi. “Atatürk ve Çocuk Müzesi.” Erişim 10 Eylül 2019. http://yalovakentmuzesi. gov.tr/turizm/tigem-ataturk-ve-cocuk-muzesi/

https://www.historymuseum.ca/visit/childrens-museum/\#kids. Erişim 24 Ekim 2019. 